\title{
PENGARUH PROFITABILITAS, LIKUIDITAS DAN SOLVABILITAS TERHADAP PEMBERIAN OPINI KEBERLANGSUNGAN USAHA PADA PERUSAHAAN JASA
}

\author{
Yovita Ariani \\ Universitas Bunda Mulia \\ ywinoto@bundamulia.ac.id
}

\begin{abstract}
The purpose of the company is to be able to gain profits and maintain their business in long term. Financial performance can be seen from financial statements made by management and audited by an independent auditor in order to obtain confidence that financial statements have been fairly stated in material terms. Financial ratios that can be obtained from financial statements can be used as indicators of company's performance, including if the company was experiencing problems or threats regarding the sustainability of its business. This study discussed the influence of financial indicators such as profitability, liquidity, and solvency as independent variables on going concern audit opinion as the dependent variable. This research was conducted on service sector companies, subsector retail and wholesale trade, listed on the Indonesia Stock Exchange (IDX) in 2017 and 2018. Samples were collected by purposive sampling and hypothesis testing was carried out using multiple regression. Analysis tool used in this research was Statistical Package for Service Sollution 24 (SPSS 24) with a significance level of 0.05. The results showed that profitability and solvency partially had an influence on going concern opinion, while liquidity had no effect. Together, the three independent variables have an influence on going concern opinion.
\end{abstract}

Keyword : profitability, liquidity, solvency, going concern opinion, service sector

ABSTRAK: Tujuan dari perusahaan adalah agar dapat memperoleh keuntungan dan mempertahankan usahanya dalam waktu yang lama. Kinerja keuangan dapat dilihat dari laporan keuangan yang dibuat oleh manajemen dan telah diaudit oleh auditor independen agar dapat memperoleh keyakinan bahwa laporan keuangan telah dibuat secara wajar dalam hal yang material. Rasio-rasio keuangan yang dapat diperoleh dari laporan keuangan dapat dijadikan indikator mengenai kinerja perusahaan termasuk apabila perusahaan sedang mengalami masalah atau ancaman mengenai keberlangsungan usahanya. Dalam penelitian ini dibahas mengenai pengaruh indikator keuangan seperti profitabilitas, likuiditas, dan solvabilitas sebagai variabel independen terhadap pemberian opini audit keberlangsungan usaha sebagai variabel dependen. Penelitian ini dilakukan pada perusahaan sektor jasa dengan subsektor perdangangan besar dan eceran yang terdaftar di Bursa Efek Indonesia (BEI) tahun 2017 dan 2018. Pemilihan sampel menggunakan purposive sampling dan uji hipotesis dilakukan dengan menggunakan regresi berganda dan alat bantu Statistical Package for Service Sollution 24 (SPSS 24) dengan tingkat signifikasi 0.05. Hasil penelitian menunjukan bahwa profitabilitas dan solvabilitas secara parsial memiliki pengaruh atas opini keberlangsungan usaha, sedangkan likuiditas tidak berpengaruh. Secara bersama-sama ketiga variabel independen memiliki pengaruh terhadap pemberian opini keberlangsungan usaha.

Kata Kunci: profitabilitas, likuiditas, solvabilitas, opini keberlangsungan usaha, sektor jasa

\section{Pendahuluan}

\subsection{Latar Belakang}

Didalam dunia bisnis tentunya tujuan dari perusahaan adalah mencapai keuntungan dan dapat bertahan dalam industri dalam waktu yang lama. Melalui strategi dan kebijakan yang dibuat mereka berusaha untuk terus berkembang dan menjaga agar bisnis mereka tidak mengalami kerugian dan dapat menarik minat investor untuk menanamkan modal di perusahaan 
mereka. Para investor tentunya membutuhkan informasi mengenai keadaan dan kinerja perusahaan sehingga mereka dapat memberikan keputusan apakah akan menanamkan investasi mereka ke perusahaan yang mereka targetkan atau sebaliknya. Kinerja dari bisnis perusahaanperusahaan ini tercermin dalam laporan keuangan yang dibuat oleh manajemen. Tujuan dari laporan keuangan adalah untuk memberikan informasi mengenai posisi keuangan, kinerja keuangan dan juga arus kas entitas yang bermanfaat bagi sebagian besar kalangan pengguna laporan dalam pembuatan keputusan ekonomi (PSAK No. 1, 2015). Berbeda dengan tujuan dari para investor, pihak manajemen tentunya berusaha agar kinerja keuangan yang tercermin dalam laporan keuangan terlihat baik dan menguntungkan. Perbedaan kepentingan ini tentunya menyebabkan adanya kebutuhan untuk para investor agar dapat meningkatkan kepercayaan terhadap laporan keuangan yang dibuat oleh manajemen. Perbedaan kepentingan ini dikenal dengan nama teori keagenan (agency theory) yang menyatakan bahwa adanya hubungan yang berdasarkan pada kontrak yang terjadi antar anggotaanggota dalam perusahaan, yakni antara pemilik (principal) dan agen (agent) sebagai pelaku utama (Jensen \& Meckling, 1976). Dengan adanya hal tersebut maka jasa auditor sebagai pihak eksternal diperlukan untuk memeriksa apakah laporan yang dibuat oleh manajemen telah menyajikan secara wajar seluruh informasi keuangan yang diperlukan oleh para pemangku kepentingan termasuk para investor dalam pengambilan keputusan.

Berdasarkan laporan keuangan yang telah diaudit oleh pihak independen yaitu auditor, maka laporan keuangan dapat dijadikan indikasi apakah perusahaan telah mencapai tujuannya yaitu mencapai keuntungan dan keberlangsungan usaha (going concern) atau sebaliknya. Indikasi yang dimaksud diatas dapat dilihat dengan berbagai cara seperti melalui rasio keuangan yang terdiri dari rasio profitabilitas, rasio likuiditas dan rasio solvabilitas yang akan dibahas lebih lanjut pada bagian kajian pustaka. Indikasi lain dari keadaan perusahaan juga dapat dilihat melalui strategi bisnis perusahaan dan kebijakan perusahaan baik kebijakan yang terkait investasi maupun kebijakan pengeloaan hutang. Informasi lain seperti peraturan pemerintah dan tuntutan hukum terhadap perusahaan juga dapat menentukan keadaan perusahaan apakah menguntungkan atau merugikan perusahaan. Sebagai pihak eksternal yang ditunjukan oleh para pemangku kepentingan, atas hasil pekerjaannya, auditor mengeluarkan suatu opini yang dapat berupa opini wajar tanpa pengecualian (unqualified), opini wajar dengan pengecualian (qualified), opini tidak menyatakan pendapat (disclaimer) dan yang terakhir opini tidak wajar (adverse). Dalam kasus disaat auditor tidak yakin atas keberlangsungan usaha perusahaan, auditor dapat menyatakan pendapat wajar dengan penekanan pada suatu hal atau qualified, jika seluruh laporan keuangan telah disusun secara wajar menurut standar keuangan yang ada di Indonesia. Penekanan pada suatu hal terkait keberlangsungan usaha, yang diberikan oleh auditor dapat dijadikan perhatian bagi para investor dalam keputusan investasi mereka. Alasan pemberian opini wajar dengan pengecualian ini yang terkait dengan keberlangsungan usaha dapat disebabkan berbagai hal seperti perusahaan menderita kerugian yang besar, tuntuan hukum maupun ketidakmampuan dalam membayar hutang dan alasan lainnya. 
Penelitian ini difokuskan pada perusahaan yang bergerak dibidang jasa dengan sektor perdangangan, jasa dan investasi dengan fokus pada subsektor perdagangan yaitu perdangangan besar dan eceran yang terdaftar di Bursa Efek Indonesia (BEI) tahun 2017 dan 2018 sebagai objek penelitian di Indonesia. Penelitian difokuskan pada subsektor perdangangan besar dan eceran, dikarenakan subsektor tersebut merupakan salah satu penopang utama dalam pertumbuhan ekonomi Indonesia 2018.

\subsection{Identifikasi Masalah}

Laporan keuangan bertujuan untuk memberikan informasi bagi para pemangku kepentingan dalam pengambilan keputusan sehingga diperlukan informasi yang akurat dan dapat diandalkan yang berupa laporan keuangan yang telah diaudit oleh auditor independen berupa opini. Atas dasar masalah yang diuraikan diatas maka rumusan permasalahan dalam penelitian ini adalah:

1. Apakah rasio profitabilitas mempengaruhi keputusan auditor dalam memberikan opini keberlangsungan usaha?

2. Apakah rasio likuiditas mempengaruhi keputusan auditor dalam memberikan opini keberlangsungan usaha?

3. Apakah rasio solvabilitas mempengaruhi keputusan auditor dalam memberikan opini keberlangsungan usaha?

\subsection{Tujuan dan Manfaat}

Tujuan dari penelitian ini tentunya untuk dapat menjawab permasalahan yang telah dirumuskan diatas yaitu:

1. Mengetahui apakah rasio profitabilitas berpengaruh terhadap keputusan auditor dalam memberikan opini keberlangsungan usaha.

2. Mengetahui apakah rasio likuiditas mempengaruhi keputusan auditor dalam memberikan opini keberlangsungan usaha.

3. Mengetahui apakah rasio solvabilitas mempengaruhi keputusan auditor dalam memberikan opini keberlangsungan usaha.

Dari hasil penelitian ini diharapkan bahwa bagi para investor agar dapat memprediksi hal-hal yang dapat dijadikan perhatian utama dari rasio keuangan dalam pengambilan keputusan terkait keberlangsungan usaha.

\section{Kajian Pustaka}

\subsection{Teori Keagenan}

Dalam teori agensi terdapat asumsi bahwa adanya konflik antara pemilik (principal) dan manajer (agen) yang disebabkan adanya kepentingan yang tidak sejalan diantara 2 (dua) pihak tersebut. (Schroeder, Clark \& Cathey, 2014) seperti yang disajikan kembali oleh Pratiwi 2017. Adanya perbedaan kepentingan ini menyebabkan principal membutuhkan pihak independen untuk mengawasi para agen dalam menjalankan aktivitas operasi perusahaan, salah satunya adalah melalui audit.

\subsection{Auditing}

Auditing adalah pengumpulan dan evaluasi bukti tentang informasi untuk menentukan dan melaporkan kesesuaian antara informasi dengan kriteria yang telah ditetapkan. (Arens, 2015). Audit harus dilakukan oleh orang yang independen dan kompeten sehingga dapat menghasilkan kesimpulan atas laporan keuangan yang dapat diandalkan.

\subsection{Opini}

Opini auditor merupakan pendapat yang diberikan oleh auditor tentang kewajaran penyajian laporan keuangan pada hasil audit. Hasil akhir dari proses auditing adalah pendapat auditor atas laporan keuangan perusahaan 
Berdasarkan pengertian tersebut dapat disimpulkan bahwa opini audit merupakan pernyataan auditor mengenai kewajaran laporan keuangan. Menut Hayes et. al, dalam buku Principles of Auditing tahun 2017, mengacu kepada hasil audit, opini auditor dapat dibedakan menjadi 4 (empat) yaitu:

a. Wajar tanpa pengecualian (unqualified). Opini ini dapat disebut opini tanpa modifikasi. Opini ini diberikan pada saat auditor menyimpulkan bahwa laporan keuangan telah dibuat dalam hal yang material sesuai dengan kerangka pelaporan yang berlaku.

b. Wajar dengan pengecualian (qualified). Opini ini diberikan pada saat kondisi berikut:

- Auditor memperoleh bukti yang cukup bahwa kesalahan baik secara individu maupun bersama-sama adalah material tetapi tidak pervasif pada laporan keuangan

- Auditor tidak dapat memperoleh bukti yang cukup untuk memberikan opini, tetapi auditor menyimpulkan bahwa dampak yang dapat ditimbulkan dari hal tersebut dapat material tetapi tidak pervasif.

c. Tidak menyatakan pendapat (disclaimer). Opini ini diberikan pada saat auditor tidak dapat memperoleh bukti yang cukup untuk mendasari pemberian opini dan auditor menyimpulkan kemungkinan kesalahan yang tidak dapat dideteksi dapat material dan pervasif.

d. Tidak wajar (adverse). Opini ini diberikan pada saat auditor telah memperoleh bukti yang cukup dan dapat menarik kesimpulan bahwa kesalahan baik secara individu maupun bersama-sama adalah material dan pervasif.

\begin{abstract}
Kesalahan material yang dimaksud dalam pemberian opini adalah kesalahan yang dapat mempengaruhi keputusan ekonomi. Sedangkan pervasif adalah kesalahan tersebut dapat mempengaruhi secara luas dari laporan keuangan.
\end{abstract}

\subsection{Going Concern}

Menurut Altman dan McGough (1974), seperti yang ditulis kembali oleh Putri (2018), masalah going concern terbagi menjadi 2 (dua), yaitu masalah keuangan yang meliputi kekurangan (defisiensi) likuiditas, defisiensi ekuitas, penunggakan hutang, kesulitan memperoleh dana serta kerugian yang terus-menerus, prospek pendapatan yang meragukan dan pengendalian internal yang lemah.

Pemberian opini audit dengan penekanan pada masalah keberlangsungan usaha dapat dijadikan indikasi bahwa perusahaan tidak dapat melanjutkan kegiatan usahanya di masa depan sehingga dapat digunakan untuk membantu para investor dalam pengambilan keputusan apakah akan menanamkan modal mereka atau tidak. Auditor harus mempertimbangkan berbagai hal dalam pemberian opini tersebut, tidak terlepas dari keadaan ekonomi secara keseluruhan dan rencana perusahaan di masa yang akan datang.

Menurut Arens (2017), terdapat beberapa faktor yang dapat menimbulkan ketidakpastian mengenai kelangsungan hidup perusahaan yaitu:

a. Kerugian usaha yang besar secara berulang atau kekurangan modal kerja.

b. Ketidakmampuan perusahaan untuk membayar kewajibannya pada saat jatuh tempo dalam jangka pendek.

c. Kehilangan pelanggan utama, terjadinya bencana yang tidak diasuransikan

d. Perkara pengadilan, gugatan hukum yang dapat membahayakan 
kemampuan perusahaan untuk beroperasi.

\subsection{Rasio}

a. Profitabilitas

Menurut Harahap (2013) rasio Profitabilitas menggambarkan kemampuan perusahaan mendapatkan laba melalui semua kemampuannya, dan sumber yang ada. Semakin baik rasio Profitabilitas, maka semakin baik menggambarkan kemampuan tingginya perolehan keuntungan pada perusahaan.

Menurut Kasmir (2016), secara umum ada 4 jenis analisis utama yang digunakan untuk menilai tingkat Profitabilitas yaitu:

- Net Profit Margin (NPM)

Rasio ini menggambarkan penghasilan bersih perusahaan berdasarkan total penjualan.

- Return on Assets (ROA)

Rasio ini menunjukkan kemampuan perusahaan dalam menghasilkan laba dari jumlah aset yang tersedia.

- Return on Equity (ROE)

Rasio ini mengukur kemampuan perusahaan dalam memperoleh laba yang tersedia untuk pemegang saham perusahaan.

- Earning Per Share (EPS)

Rasio yang menggambarkan jumlah uang yang akan dihasilkan dari setiap lembar saham biasa yang dimiliki investor.

b. Likuiditas

Menurut Harahap (2013), rasio Likuiditas merupakan rasio yang mengukur kemampuan perusahaan memenuhi

kewajiban jangka pendeknya. Jenis-jenis rasio likuiditas yang dikemukakan oleh Kasmir (2016) yaitu:

- Rasio Lancar (Current Ratio)

Rasio untuk mengukur kemampuan perusahaan dalam membayar kewajiban jangka pendek

- Rasio Cepat (Quick Ratio)

Rasio yang menunjukkan kemampuan perusahaan dalam memenuhi utang lancar (utang jangka pendek) dengan aktiva lancar tanpa mempertimbangkan nilai persediaan (inventory).

- Rasio Kas (Cash Ratio)

Mengukur seberapa besar uang kas yang tersedia untuk membayar utang

c. Solvabilitas

Irham Fahmi (2014) bahwa rasio Solvabilitas merupakan rasio yang menunjukkan bagaimana perusahaan mampu untuk mengelola utangnya dan juga mampu untuk melunasi kembali utangnya tepat waktu.

Adapun jenis-jenis rasio yang ada dalam rasio Solvabilitas menurut Kasmir (2016) antara lain:

- Debt to total asset ratio (Debt Ratio) adalah ratio yang digunakan untuk mengukur seberapa besar aktiva perusahaan dibiayai oleh utang

- Debt to equity Ratio adalah ratio yang digunakan untuk menilai utang dengan ekuitas.

- Long term debt to equity ratio adalah untuk mengukur berapa bagian dari setiap rupiah modal sendiri yang dijadikan jaminan utang jangka panjang

- Times Interest Earned (TIER) adalah untuk mengukur sejauh mana pendapatan dapat menurun tanpa membuat perusahaan merasa malu karena tidak mampu membayar biaya bunga tahunannya.

- Fixed Charge Coverage

Perbedaan dengan TIER, adalah rasio ini dilakukan apabila perusahaan memperoleh utang jangka panjang atau menyewa aktiva berdasarkan kontrak sewa (lease contract). Biaya tetap 
merupakan biaya bunga ditambah kewajiban sewa tahunan atau jangka panjang.

\subsection{Penelitian terdahulu}

Penelitian mengenai pengaruh profitabilitas, likuiditas dan solvabilitas terhadap pemberian opini going concern telah dilakukan oleh peneliti terdahulu dengan tahun penelitian dan sektor serta sample penelitian yang berbeda. Kurniawati (2017) pada penelitian yang berjudul Pengaruh profitabilitas, likuiditas, dan ukuran perusahaan terhadap opini going concern yang dilakukan melalui studi kasus pada perusahaan tekstil dan garmen yang terdaftar di bursa efek Indonesia 2011 - 2016 menyatakan bahwa profitabilitas, likuiditas dan ukuran perusahaan berpengaruh secara signifikan terhadap pemberian opini going concern baik secara bersama-sama maupun secara parsial. Pemberian opini audit going concern, dipengaruhi oleh berbagai kondisi yaitu kondisi keuangan dan non-keuangan seperti yang dikemukakan oleh Kartika (2012) dalam penelitian yang berjudul pengaruh kondisi keuangan dan nonkeuangan terhadap pemberian opini going concern. Hasil penelitian menujukan bahwa kondisi keuangan, tidak berpengaruh terhadap penerimaan opini going concern sedangkan opini audit tahun sebelumnya dan pertumbuhan perusahaan berpengaruh terhadap penerimaan opini going concern. Penelitian yang dilakukan oleh Fitriani (2018), menunjukan bahwa hanya likuiditas secara parsial memiliki pengaruh dalam pemberian opini going concern. Sedangkan untuk profitabilitas tidak memiliki pengaruh. Adanya perbedaan-perbedaan dalam penelitian terdahulu dalam hal sektor, sample, periode dan hasil penelitian, maka dalam penelitian ini akan dilihat pengaruh kondisi keuangan melalui rasio-rasio keuangan terhadap pemberian opini audit tentang keberlangsungan usaha atau going concern.

\section{Metode Penelitian}

\subsection{Jenis, Metode dan Populasi}

Penelitian ini menggunakan metode kuantitatif dengan menggunakan elemen-elemen dalam laporan keuangan sebagai variable penelitian. Populasi dalam penelitian ini menggunakan data sekunder yang diperoleh dari laporan tahunan perusahaan yang difokuskan pada subsektor perdagangan besar dan eceran dari tahun 2017 dan 2018 yang terdaftar di Bursa Efek Indonesia (BEI). Data sekunder ini diperoleh peneliti dari website BEI, yaitu www.idx.co.id.

Dalam penelitian ini menulis menggunakan metode analisis pengaruh, yaitu regresi linier. Regresi linier merupakan analisis untuk mengetahui pengaruh atas hubungan secara linier antar variable independent terhadap variable dependen, dan untuk memprediksi atau meramalkan suatu nilai variable dependen berdasarkan variable independent. Software yang digunakan untuk membantu mengolah data pada penelitian ini adalah SPSS (Statistical Package for Service Sollution), yaitu software yang berfungsi untuk menganalisis data dan melakukan perhitungan secara statistik.

\subsection{Sampel}

Metode pemilihan sampel yang digunakan dalam penelitian ini adalah purposive sample yang merupakan metode penetapan responden untuk dijadikan sampel berdasarkan pada kriteria-kriteria tertentu. Adapun kriteria pemilihan sampel pada penelitian ini adalah:

1. Perusahaan subsektor perdagangan besar dan eceran yang terdaftar di BEI pada tahun 2017-2018.

2. Perusahaan subsektor perdagangan besar dan eceran yang menyajikan 
laporan keuangan dalam mata uang rupiah (Rp.).

3. Perusahaan tidak keluar atau delisting selama periode penelitian.

4. Perusahaan subsektor perdagangan besar dan eceran yang mengeluarkan laporan auditor independent selama periode penelitian.

5. Perusahaan subsektor perdagangan besar dan eceran yang pernah mengalami laba bersih setelah pajak yang negatif selama periode penelitian.

\subsection{Pengukuran Variabel}

Variabel penelitian adalah suatu atribut atau sifat atau nilai dari orang, objek atau kegiatan yang mempunyai variasi tertentu yang ditetapkan oleh peneliti untuk dipelajari dan kemudian ditarik kesimpulannya (Sugiyono, 2015) seperti yang telah ditulisk kembali oleh Adhityan pada 2018.

\section{Variabel Dependen (Y)}

Variabel dependen dalam penelitian ini adalah keberlangsungan usaha (going concern). Opini Audit Going Concern merupakan opini audit modifikasian yaitu opini dengan penekanan pada suatu hal sehubungan dengan pertimbangan auditor terdapat keraguan atau ketidakpastian material atas kelangsungan hidup perusahaan dalam mempertahankan operasinya di masa yang akan datang. Variabel Opini

Audit Going Concern diukur dengan menggunakan variabel dummy. Perusahaan subsektor perdangangan besar dan eceran yang menerima opini audit going concern akan termasuk dalam kategori 1 dan perusahaan yang tidak menerima opini going concern akan termasuk kategori 0.

\section{Variable Independen $(X)$}

Penelitian ini tidak menggunakan semua rasio yang ada pada masingmasing rasio, tetapi hanya terbatas pada variabel berikut: a. Profitabilitas (X1)

Rasio

profitabilitas menggambarkan kemampuan perusahaan mendapatkan laba dengan menggunakan semua sumber daya yang dimilikinya. Dalam penelitian ini, rasio profitabilitas yang digunakan adalah profit margin dengan formula berikut:

$$
\text { Profit margin }=\frac{\text { Laba sesudah pajak }}{\text { Penjualan bersih }}
$$

Makin rendah laba sesudah pajak maka profit margin yang dihasilkan akan semakin kecil sehingga perusahaan dapat terancam dalam mempertahankan usahanya.

b. Likuiditas (X2)

Rasio likuiditas menggambarkan kemampuan perusahaan untuk memenuhi kewajiban jangka pendeknya. Parameter yang digunakan dalam rasio ini adalah current ratio dengan formula sebagai berikut:

$$
\text { Current Ratio }=\frac{\text { Aset Lancar }}{\text { Kewajiban Lancar }}
$$

Semakin besar kewajiban lancar atau kewajiban jangka pendek perusahaan dibandingkan dengan asset lancar maka kemampuan untuk membayar kewajiban jangka pendek perusahaan, biasanya dinyatakan dalam hutang perusahaan, diragukan sehingga jika perusahaan tidak mampu untuk membayar kemapuan jangka pendek maka dapat dikatakan perusahaan keberlangsungan usaha perusahaan dapat terancam.

c. Solvabilitas (X3)

Mengambarkan kemampuan perusahaan dalam membayar kewajiban jangka panjangnya. Parameter yang digunakan dalam penelitian ini adalah debt ratio dengan formula sebagai berikut: 


$$
\text { Debt ratio }=\frac{\text { Total Aset }}{\text { Total Kewajiban }}
$$

\subsection{Teknik Analisis Data}

Dalam penelitian ini, peneliti menggunakan langkah-langkah berikut dalam melakukan analisis data:

a. Statistik Deskriptif

Seperti yang diungkapkan oleh Priyatno dalam "SPSS 22 Pengolah Data Terpraktis", analisis deskriptif digunakan untuk penggambaran tentang statistic data seperti min, max, mean, sum, standar deviasi dan lainnya. Analisis deskriptif digunakan untuk mendeskripsikan atau menggambarkan data yang telah terkumpul tanpa bermaksud membuat kesimpulan yang berlaku untuk umum.

b. Uji Asumsi Klasik

$\begin{array}{lcr}\text { Uji ini } & \text { digunakan } & \text { untuk } \\ \text { mengetahui } & \text { ada } & \text { tidaknya } \\ \text { normalitas } & & \text { residual, }\end{array}$
multikolinearitas, autokorelasi, dan heteroskedastis pada model regresi. Suatu model regresi dapat dikatakan baik jika memenuhi beberapa asumsi klasik sehingga dapat diperoleh estimasi yang tidak bias dan penggujian dapat terpercaya. Uji normalitas residual yang digunakaan dalam penelitian ini adalah metode grafik, dalam uji mutlikolinearitas, peneliti akan melihat nilai tolerance dan inflatation factor (VIF) pada model regresi, pada autokorelasi, peneliti akan mengacu kepada nilai Durbin Watson, sedangkan pada uji heteroskedastis akan menggunakan metode Spearman's rho dengan mengkorelasikan variabel independent dengan residualnya.

c. Pengujian Hipotesis

Analisis regresi linier berganda digunakan dalam pengujian hipotesis untuk mengetahui pengaruh atau hubungan secara linier antara dua atau lebih variabel independen dengan satu variabel dependen. Model regresi yang digunakan dalam penelitian ini adalah sebagai berikut:

$$
Y^{\prime}=a+b_{1} X_{1}+b_{2} X_{2}+b_{3} X_{3}
$$

Keterangan:

- $\mathrm{Y}^{\prime}$ : Nilai prediksi variabel dependen (opini going concern)

- a : Konstanta, yaitu nilai $Y^{\prime}$ jika $X_{1}, X_{2}$ dan $X_{3}=0$

- $b_{1}, b_{2}, b_{3}$ : Koefisien regresi, yaitu nilai peningkatan atau penurunan variable $\mathrm{Y}^{\prime}$ yang didasarkan variabel $\mathrm{X}_{1}, \mathrm{X}_{2}$ dan $\mathrm{X}_{3}$.

- $\mathrm{X}_{1}$ : Variabel independen (profit margin)

- $\mathrm{X}_{2}$ : Variabel independen (current ratio)

- $\mathrm{X}_{3}$ : Variabel independent (debt ratio)

\section{Hasil dan Pembahasan}

a. Statistik Deskriptif

Dalam penelitian ini, analisis deskriptif dimanfaatkan untuk menggambarkan data statistik yang sudah dikumpulkan tanpa bermaksud membuat suatu simpulan yang berlaku umum atau generalisasi (Priyatno, 2014). Berikut tabel statistik deskriptif dalam penelitian ini.

Dari tabel 4.1 dapat dilihat bahwa jumlah data dari masing-masing variabel adalah 36 data. Variabel profit margin memiliki nilai minimum $4.73 \%$ dan maksimum $0.17 \%$ dengan tingkat rata-rata $-0.28 \%$ dan standar deviasi 0.82631 . 
Tabel 4.1: Statistik Deskriptif

\begin{tabular}{|c|c|c|c|c|c|}
\hline \multicolumn{6}{|c|}{ Statistics } \\
\hline & & \begin{tabular}{|c|} 
Opini Going \\
Concern
\end{tabular} & $\begin{array}{l}\text { Profit } \\
\text { Margin }\end{array}$ & Current Ratio & Debt Ratio \\
\hline \multirow[t]{2}{*}{$N$} & Valid & 36 & 36 & 36 & 36 \\
\hline & Missing & 0 & 0 & 0 & 0 \\
\hline \multicolumn{2}{|c|}{ Mean } & 0.3056 & -0.2777 & 4.9153 & 2.4741 \\
\hline \multicolumn{2}{|c|}{ Median } & 0.0000 & -0.0227 & 1.1214 & 0.8499 \\
\hline \multicolumn{2}{|c|}{ Mode } & 0.00 & $-4.73^{\mathrm{a}}$ & $.09^{\mathrm{a}}$ & $.01^{\mathrm{a}}$ \\
\hline \multicolumn{2}{|c|}{ Std. Deviation } & 0.46718 & 0.82631 & 19.54653 & 5.17697 \\
\hline \multicolumn{2}{|c|}{ Range } & 1.00 & 4.90 & 118.14 & 19.96 \\
\hline \multicolumn{2}{|c|}{ Minimum } & 0.00 & -4.73 & 0.09 & 0.01 \\
\hline \multicolumn{2}{|c|}{ Maximum } & 1.00 & 0.17 & 118.22 & 19.97 \\
\hline \multicolumn{2}{|c|}{ Sum } & 11.00 & -10.00 & 176.95 & 89.07 \\
\hline
\end{tabular}

a. Multiple modes exist. The smallest value is shown

Sumber: Hasil olahan data

Dari data ini dapat terlihat bahwa profit margin bervariasi antar data dengan selisih $4.9 \%$ dari nilai terkecil dan terbesar. Hal ini menunjukan bahwa besarnya profit bervariasi dalam pemberian opini going concern. Current ratio memiliki nilai minimum 0.09 dan maksimum 118.22. Nilai maksimum dimiliki oleh PT Akbar Indo Makmur Stimec yang disebabkan nilai aset lancar perusahaan sebesar lima belas miliar rupiah dibandingkan dengan kewajiban lancar perusahaan yang hanya sebesar seratus dua puluh tujuh juta rupiah. Nilai rata-rata debt ratio adalah sebesar 2.47 sehingga dapat dikatakan rata-rata perusahaan dalam sampel memiliki total aset lebih banyak sebesar 2.47 kali dibandingkan dengan total kewajiban yang memiliki potensi dalam mendapatkan opini going concern.

\section{b. Uji Asumsi Klasik}

Uji asumsi klasik yang pertama adalah uji normalitas untuk mengetahui apakah data berdistribusi normal atau tidak. Normalitas data merupakan syarat pokok yang harus dipenuhi dalam analisis parametrik, karena dengan data yang terdistribusi normal, maka data tersebut dapat dianggap mewakili populasi.

Dari gambar 4.1 pada uji normalitas dapaat dilihat bahwa data mengikuti grafik histogramnya. Hal ini sejalan dengan Priyatno (2014) yang menyatakan bahwa pada dasarnya normalitas sebuah data dapat dikenali dari persebaran data dari grafik histogram. Hal ini juga diperkuat dengan asumsi bahwa data yang digunakan dalam penelitian ini adalah sudah lebih dari 30 sampel maka diasumsikan bahwa data telah terdistribusi secara normal. 


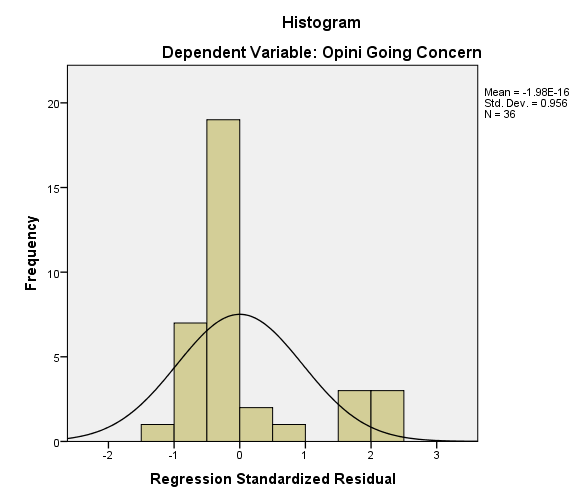

Uji asumsi klasik yang kedua adalah multikolinearitas untuk melihat apakah antar variabel independen yang terdapat dalam model regresi memiliki hubungan linier yang sempurna atau mendekati sempurna. Model regresi yang baik seharusnya tidak terjadi korelasi sempurna.

Gambar 4.1: Hasil Uji Normalitas Histogram

Tabel 4.2: Hasil Uji Multikolinieritas

\begin{tabular}{|llll|}
\hline & & \multicolumn{2}{c|}{ Collinearity Statistics } \\
\cline { 3 - 4 } Model & & Tolerance & VIF \\
\hline 1 & (Constant) & & \\
& Profit Margin & 0.993 & 1.007 \\
& Current Ratio & 0.985 & 1.015 \\
& Debt Ratio & 0.983 & 1.017 \\
\hline
\end{tabular}

Sumber: Hasil olahan data

Pada uji multikoliniaritas, peneliti melihat nilai tolerance dan inflation factor (VIF) pada model regresi. Pada tabel 4.2 menunjukan VIF dari profit margin adalah 1.007 dan tolerance 0.993 , current ratio memiliki VIF 1.015 dan tolerance 0.985 sedangkan debt ratio memiliki VIF 1.017 dan tolerance 0.983 . Dari ketiga variabel dapat lihat bahwa nilai VIF kurang dari 10 dan tolerance lebih dari 0.1, sehingga dapat dinyatakan tidak terjadi multikolinieritas (Ghozali, 2018).

Uji asusmsi klasik yang ketiga adalah uji autokorelasi untuk melihat korelasi antara anggota observasi yang disusun menurut waktu atau tempat. Model regresi yang baik seharusnya tidak terjadi autokorelasi. Pada penelitian ini, peneliti menggunakan uji DurbinWatson (DW test), dengan keputusan sebagai berikut:
- DU < DW <4-DU maka Ho diterima, tidak terjadi autokorelasi

- DW < DL atau DW > 4-DL, Ho ditolak, terjadi autokorelasi

- DL < DW < DU atau 4-DU < DW $<4-\mathrm{DL}$ artinya tidak terdapat kesimpulan yang pasti.

Nilai DL dan DU diperoleh dari tabel statistik Durbin-Watson, dengan $\mathrm{n}=$ 36 dan $\mathrm{K}=3$ sehingga nilai $\mathrm{DL}=$ 1.5872 dan $\mathrm{DU}=1.2953$. Dari hasil tersebut diperoleh nilai $4-\mathrm{DL}=4-$ $1.5872=2.4148$ dan $4-\mathrm{DU}=4-$ $1.2953=2.7047$. Berdasarkan tabel 4.3 nilai DW adalah 1.396 sehingga $1.2953<1.396<2.7047$ sehingga dapat disimpulkan tidak terjadi autokorelasi.

Tabel 4.3: Hasil Uji Autokorelasi 


\begin{tabular}{|lccccc|}
\hline \multicolumn{7}{|c|}{ Model Summary $^{\mathrm{b}}$} \\
\hline Model & $\mathrm{R}$ & $\mathrm{R}$ Square & $\begin{array}{c}\text { Adjusted } \\
\text { Square }\end{array}$ & $\begin{array}{c}\text { Std. Error of the } \\
\text { Estimate }\end{array}$ & $\begin{array}{c}\text { Durbin- } \\
\text { Watson }\end{array}$ \\
\hline 1 & $.672^{\mathrm{a}}$ & 0.451 & 0.400 & 0.36193 & 1.396 \\
\hline
\end{tabular}

a. Predictors: (Constant), Debt Ratio, Profit Margin, Current Ratio

b. Dependent Variable: Opini Going Concern

Sumber: Hasil olahan data

Uji yang terakhir pada uji asumsi klasik yaitu uji heteroskedastisitas untuk melihat varian residual yang tidak sama pada semua pengamatan di dalam model regresi. Pada uji ini, peneliti menggunakan metode korelasi
Spearman's rho. Pengujian menggunakan tingkat signifikasi 0.05 dengan 2 (dua) sisi.

Tabel 4.2: Hasil uji heteroskedastisitas

\begin{tabular}{|c|c|c|c|c|c|c|}
\hline \multicolumn{7}{|c|}{ Correlations } \\
\hline & & & $\begin{array}{c}\text { Profit } \\
\text { Margin }\end{array}$ & $\begin{array}{l}\text { Current } \\
\text { Ratio }\end{array}$ & Debt Ratio & $\begin{array}{l}\text { Unstandardized } \\
\text { Residual }\end{array}$ \\
\hline \multirow[t]{3}{*}{ Spearman's rho } & \multirow{3}{*}{$\begin{array}{l}\text { Unstandardized } \\
\text { Residual }\end{array}$} & Correlation Coefficient & 0.065 & 0.211 & 0.033 & 1.000 \\
\hline & & Sig. (2-tailed) & 0.707 & 0.218 & 0.848 & \\
\hline & & $\mathrm{N}$ & 36 & 36 & 36 & 36 \\
\hline
\end{tabular}

Sumber: Hasil olahan data

Dari tabel 4.2 dilihat bahwa korelasi antara variabel profit margin, current ratio dan debt ratio dengan unstandardized residual adalah masing-masing sebesar $0.707,0.218$ dan 0.848. Nilai ini lebih dari 0.05 sehingga dapat disimpulkan bahwa tidak terjadi masalah heteroskedasisitas (Priyatno, 2014).

Berdasarkan hasil dari semua uji asumsi klasik, langkah selanjutnya adalah melakukan pengujian hipotesis untuk dapat menarik suatu kesimpulan mengenai model regresi.

c. Pengujian Hipotesis

Pengujian hipotesis dilakukan dengan menggunakan pendekatan analisis regresi linier berganda untuk kemudian dilakukan uji $\mathrm{F}$ atau ANOVA dan uji t untuk mengetahui uji koefisien regresi secara parsial.

\section{Uji regresi berganda}

Berdasarkan tabel 4.2. diatas dapat diketahui bahwa persamaan regresi linier berganda sebagai berikut:
$\mathrm{Y}^{\prime}=0.133-0.208 \mathrm{X}_{1}-0.003 \mathrm{X}_{2}+$ $0.051 X_{3}$

Persamaan diatas dapat dijelaskan sebagai berikut:

a. Konstanta : Nilai konstanta yang diperoleh adalah 0.133. Hal ini berarti bahwa jika variabel independent adalah nol, maka pesarnya nilai opini going concern adalah sebesar konstanta 0.133 .

b. Koefisien regresi $\left(\mathrm{X}_{1}\right)$ - profit margin : Nilai koefisien regresi variabel profit margin adalah sebesar -0.208 . Hal ini menandakan bahwa setiap peningkatan satu satuan profit margin akan mengakibatkan penurunan nilai pemberian opini going concern sebesar 0.208.

c. Koefisien regresi $\left(\mathrm{X}_{2}\right)$ - current ratio: Nilai koefisien regresi variabel current ratio adalah sebesar -0.003 . Hal ini menandakan bahwa setiap peningkatan satu satuan current ratio akan mengakibatkan penurunan pemberian opini going concern sebesar 0.003

d. Koefisien regresi $\left(\mathrm{X}_{3}\right)$ - debt ratio: Nilai koefisien regresi variabel debt 
ratio adalah sebesar 0.051 . Hal ini menandakan bahwa setiap peningkatan satu satuan debt ratio akan mengakibatkan kenaikan pemberian opini going concern sebesar 0.051

\section{Uji F}

Uji $F$ atau ANOVA atau analisis varian merupakan uji koefisien regresi secara bersama-sama untuk menguji signifikasi pengaruh beberapa variabel independent terhadap variabel dependen. Pada pengujian ini menggunakan tingkat signifikasi 0.05. Berikut hasil dari uji F.
1. Hipotesis yang digunakan dalam uji $F$ dalam penelitian ini adalah:

Ho: Profit Margin, CR dan Debt Ratio secara Bersama-sama tidak berpengaruh terhadap Pemberian opini going concern

H1: Profit margin, CR dan Debt Ratio secara Bersama-sama berpengaruh terhadap pemberian opini going concern

2. Menentukan $F$ hitung dan nilai signifikasi.

Tabel 4.4: Hasil Uji F

\begin{tabular}{|lllrrrrr|}
\hline \multicolumn{7}{c|}{ ANOVA $^{\text {a }}$} \\
\hline \multirow{2}{*}{ Model } & & Sum of & & & & & \\
\hline 1 & Squares & df & & Mean Square & F & Sig. \\
& Regression & 3.447 & 3 & 1.149 & 8.771 & $.000^{\circ}$ \\
& Residual & 4.192 & 32 & 0.131 & & \\
& Total & 7.639 & 35 & & & \\
\hline
\end{tabular}

a. Dependent Variable: Opini Going Concern

b. Predictors: (Constant), Debt Ratio, Profit Margin, Current Ratio

Sumber: Hasil olahan data

Dari output diperoleh F hitung

8.771 dan nilai signifikasi 0.00

3. Menentukan $F$ tabel

Pada tingkat signifikasi $0.05 \mathrm{dan} \mathrm{df}$ 1 (jumlah variable -1$)=2$ dan $\mathrm{df} 2$ (n-k-1) atau $36-3-1=32$, maka hasil yang diperoleh untuk $\mathrm{F}$ table adalah 2.901

4. Kriteria pengujian

- Jika F hitung $\leq$ F table maka Ho diterima

- Jika F hitung > F table maka Ho ditolak

5. Membuat kesimpulan

F hitung > F table yaitu $8.771>$ 2.901 dan signifikasi $0.000<0.05$, maka Ho ditolak sehingga profit margin, current ratio dan debt ratio secara bersama-sama berpengaruh terhadap Pemberian opini going concern.

\section{Uji t}

Uji t atau uji koefisien regresi secara parsial digunakan untuk mengetahui apakah secara parsial profit margin, current ratio dan debt ratio berpengaruh secara signifikan atau tidak terhadap pemberian opini going concern. Pengujian ini menggunakan tingkat signifikasi 0.05 dan 2 sisi. Berikut hasil dari uji t.

1. Hipotesis yang digunakan dalam uji t penelitian ini adalah:

Ho : Profit Margin / CR / Debt ratio secara partial tidak berpengaruh terhadap pemberian opini going concern

H1 : Profit Margin / CR / Debt ratio secara partial berpengaruh terhadap pemberian opini going concern

2. Menentukan $\mathrm{t}$ hitung dan nilai signifikasi

3. Menentukan t table 
Dengan tingkat signifikasi $0.05 / 2=$ 0.025 dengan derajat kebebasan $(\mathrm{df})=\mathrm{n}-\mathrm{k}-1$ atau $36-3-1=32$, maka hasil $t$ tabel adalah -2.037

4. Kriteria pengujian

- Jika $-\mathrm{t}$ table $\leq \mathrm{t}$ hitung $\leq \mathrm{t}$ table maka Ho diterima

- Jika -t hitung $<\mathrm{t}$ table atau $\mathrm{t}$ hitung $>\mathrm{t}$ table maka Ho ditolak

Berdasarkan signifikasi

- Jika signifikasi > 0.05 maka Ho diterima
- Jika signifikasi $<0.05$ maka Ho ditolak

5. Membuat kesimpulan

Profit margin dan pemberian opini going concern

Dari tabel 4.5 didapat bahwa $\mathrm{t}$ hitung untuk profit margin adalah 2.795 dan signifikasi 0.009 . Sehingga jika dibandingkan dengan $\mathrm{t}$ tabel maka $\mathrm{t}$ hitung $<\mathrm{t}$ table yaitu $-2795<-2.037$ sehingga Ho ditolak dan dapat ditarik

Tabel 4.5: Hasil Uji t

\begin{tabular}{|c|c|c|c|c|c|c|}
\hline \multicolumn{7}{|c|}{ Coefficients $^{a}$} \\
\hline \multirow[b]{2}{*}{ Model } & & \multicolumn{2}{|c|}{$\begin{array}{l}\text { Unstandardized } \\
\text { Coefficients }\end{array}$} & \multirow{2}{*}{$\begin{array}{c}\begin{array}{c}\text { Standardized } \\
\text { Coefficients }\end{array} \\
\text { Beta }\end{array}$} & \multirow[b]{2}{*}{$\mathrm{t}$} & \multirow[b]{2}{*}{ Sig. } \\
\hline & & $\mathrm{B}$ & Std. Error & & & \\
\hline \multirow[t]{4}{*}{1} & (Constant) & 0.133 & 0.073 & & 1.822 & 0.078 \\
\hline & Profit Margin & -0.208 & 0.074 & -0.367 & -2.795 & 0.009 \\
\hline & Current Ratio & -0.003 & 0.003 & -0.105 & -0.795 & 0.433 \\
\hline & Debt Ratio & 0.051 & 0.012 & 0.570 & 4.315 & 0.000 \\
\hline
\end{tabular}

Sumber: Hasil olahan data

kesimpulan profit secara partial berpengaruh terhadap pemberian opini going concern. Hal ini ditunjukan juga oleh tingkat signikiasi $0.009<0.05$ maka Ho ditolak. Berdasarkan hasil uji $\mathrm{t}$ tersebut, maka hal ini menunjukan bahwa perusahaan yang memiliki laba bersih negatif mempunyai kecenderungan untuk mendapatkan opini auditor mengenai keberlangsungan usaha atau going concern. Hal ini juga konsisten dengan penelitian Adhityan, 2018 dan ancaman keberlangsungan usaha menurut Arens et. al (2017) yaitu perusahaan yang mempunyai kerugian usaha yang besar secara berulang atau kekurangan modal kerja. Hasil ini pun berbeda dengan penelitian yang dilakukan oleh Putri (2018) yang menyatakan profitabilitas tidak berpengaruh terhadap pemberian opini going concern. Pada penelitian yang dilakukan oleh Okky (2018), profitabilitas memiliki pengaruh terhadap pemberian opini going concern.

\section{Current ratio dan pemberian opini going concern}

Dari tabel 4.5 didapat bahwa t hitung untuk current ratio adalah -0.795 dan signifikasi 0.433. Sehingga jika dibandingkan dengan $\mathrm{t}$ tabel maka $\mathrm{t}$ table $\leq \mathrm{t}$ hitung $\leq \mathrm{t}$ table yaitu $-2.037<$ $-0.795<2.037$ maka Ho diterima demikian juga dengan tingkat signifikasi $0.433>0.05$ maka Ho diterima, sehingga current ratio secara partial tidak berpengaruh terhadap pemberian opini going concern. Berdasarkan hasil tersebut perusahaan yang memiliki asset lancar lebih besar atau lebih kecil dibandingkan kewajiban lancar, secara partial tidak berpengaruh terhadap pemberian opini 
keberlangsungan usaha. Hal ini sesuai dengan penelitian Adhityan, 2018 yang menyatakan bahwa likuiditas, dalam hal ini current ratio, tidak berpengaruh terhadap pemberian opini audit going concern pada studi dan sektor yang berbeda.

\section{Debt ratio dan pemberian opini going concern}

Dari tabel 4.5 didapat bahwa t hitung untuk debt ratio adalah 4.315 dan signifikasi 0.00 . Sehingga jika dibandingkan dengan $\mathrm{t}$ tabel maka $\mathrm{t}$ hitung > t table yaitu $4.315>-2.037$ sehingga Ho ditolak dan sig $0.000<$ 0.05 maka Ho ditotak, dan dapat disimpulkan bahwa debt ratio secara partial berpengaruh terhadap pemberian opini going concern. Berdasarkan hasil uji t tersebut, maka hal ini menunjukan bahwa perusahaan yang memiliki total hutang yang besar dibanding dengan total aset mempunyai kecenderungan untuk mendapatkan opini auditor mengenai keberlangsungan usaha atau going concern. Hal ini juga konsisten dengan penelitian Bonita 2018 yaitu solvabilitas, debt ratio, pada studi dan sektor berbeda, memiliki pengaruh signifikan terhadap pemberian opini audit going concern. Hal ini dapat disebabkan oleh kemampuan perusahaan dalam membayar kewajiban mereka.

\section{Simpulan dan Saran}

\subsection{Kesimpulan}

Berdasarkan hasil dan pembahasan pengaruh likuiditas, profitabilitas, dan solvabilitas terhadap pemberian opini keberlangsungan usaha pada perusahaan jasa yang terdaftar di BEI tahun 2017-2018, maka dapat ditarik kesimpulan bahwa profitabilitas yang digambarkan oleh profit margin secara partial berpengaruh terhadap pemberian opini going concern. Dalam hal likuiditas yang digambarkan dengan current ratio, disimpulkan bahwa secara partial tidak berpengaruh terhadap pemberian opini going concern. Kesimpulan yang diperoleh dari solvabilitas adalah bahwa debt ratio secara partial berpengaruh terhadap pemberian opini going concern. Ketiga item rasio keuangan tersebut jika secara bersamasama yaitu profit margin, current ratio dan debt ratio berpengaruh terhadap Pemberian opini going concern.

\subsection{Saran}

Dari hasil-hasil yang didapatkan bahwa perusahaan harus memperhatikan keuntungan dalam menjaga profit margin dan rasio antara total aset dan total kewajiban agar meminimalisasi kemungkinan pemberian opini audit dengan penekanan pada masalah keberlangsungan usaha atau going concern.

Penelitian berikutnya yang akan dilakukan oleh peneliti lain dapat menggunakan variabel yang berbeda, ukuran sampel, periode penelitian dan sektor industry yang berbeda dari yang dilakukan dalam penelitian ini. Penelitian berikutnya juga diharapkan dapat meneliti lebih dalam mengenai permasalahan going concern perusahaan.

\section{Daftar Pustaka}

Adhityan, Okky (2018). Pengaruh Ukuran Perusahaan, Likuiditas, Profitabilitas, dan Solvabilitas Terhadap Opini Audit Going Concern pada Perusahaan Manufaktur yang Terdaftar di Bursa Efek Indonesia Tahun 2013-2016. Skripsi, Fakultas Ekonomi Akuntansi Universitas Negeri. Yogyakarta

Altman, E. dan McGough, T. (1974). Evaluation of A Company as A Going Concern. Journal of Accountancy. Desember 50-57 
Arens, Alvin A., Elder, Randal J., Beasley, Mark S., Hogan, C. (2017). Auditing and Assurance Services : An Integrated Approach (16th ed.). New Jersey: Pearson Prentice Hall.

Bursa Efek Indonesia (2019). Laporan Keuangan dan Tahunan Perusahaan Tercatat. Diakses 15 Juni 2019. <https://www.idx.co.id/perusahaantercat at/laporan-keuangan-dan-tahunan/>

Fahmi, Irham (2014). Pengantar Manajemen Keuangan (Teori Soal dan Jawab). Bandung: Penerbit Alfabeta

Fitriani, M., Asiah, N. (2018). Pengaruh Profitabilitas, Likuiditas, dan Ukuran Jensen, Michael C. dan William H. Meckling, (1976). Theory of The Firm: Managerial Behaviour, Agency Costs and Ownership Structure. Journal of Financial Economics, Vol.3 No. 4, 305360.

Kartika, A. (2012). Pengaruh Kondisi Keuangan dan Non-Keuangan Terhadap Penerimaan Opini Going Concern Pada Perusahaan Manufaktur di BEI. Jurnal Dinamika Akuntansi, Keuangan dan Perbankan Vol.1 No.1, 25-40

Kasmir (2016). Analisis Laporan Keuangan. Jakarta: PT. Raja Grafindo Persada

Kurniawati, E., Murti, W. (2017). Pengaruh Profitabilitas, Likuiditas, dan Ukuran Perusahaan Terhadap Opini Going Concern-Studi Kasus pada Perusahaan Tekstil dan Garmen yang Terdaftar di Bursa Efek Indonesia 2011-2016. Jurnal Akuntansi Universitas Borobudur Vol.11 No. 2, 63-76

Pernyataan Standar Akuntansi Keuangan (2015). PSAK 1-Penyajian Laporan Keuangan. Jakarta: IAI
Perusahaan Terhadap Opini Audit Going Concern. Jurnal Manajemen dan Akuntansi STIE Indonesia Vol. 19 No.2, 31-40

Ghozali, Imam (2018). Aplikasi Analisis Multivariete (ed.8). Semarang: Badan Penerbit Universitas Diponogoro

Harahap, Sofyan Syafri (2013). Analisis Kritis Atas Laporan Keuangan (ed. 11). Jakarta: Rajawali Pers

Hayes, R., Wallage, P., Gortermaker, H. (2017). Prinsip-prinsip Pengauditan: International Standards on Auditing (ed. 3) (Sopana dkk, penerjemah). Jakarta: Salemba Empat.

Pratiwi, Devica dan Kurniawan, Budi (2017). Pengaruh Penerapan Manajemen Risiko terhadap Kinerja Keuangan Industri Perbankan. Jurnal Akuntansi Bisnis Program Studi Akuntansi UBM Vol.10 No 1, 73-93.

Priyatno, Duwi (2014). SPSS 22 Pengolah Data Terpraktis. Yogyakarta: Andi

Putri, Bonita (2018). Pengaruh Profitabilitas, Likuiditas, Solvabilitas, dan Pertumbuhan Perusahaan Terhadap Opini Audit Going Concern. Skripsi, Fakultas Ekonomi Akuntansi Syarif Hidayatullah. Jakarta

Schroeder, R. G., Clark, M. W., \& Cathey, J. M. (2014). Financial Accounting Therory and Analysis Text and Cases (11th ed.). Hoboken: John Wiley \& Sons, Inc. 
